\title{
CULTURAL LABOUR AND SOCIAL AWARENESS. HOW ARTS BECOME POLITICAL - A ROMANIAN AND MOLDAVIAN STORY
}

\author{
Guest Editors' Foreword \\ MIKI BRANIȘTE1, IULIA POPOVICI²
}

Subject of great political and theoretical support following the Russian Revolution in the 1920s and widely developed in the Western world ever since the Second World War, socially-conscious and socially-engaged arts (also known as social practice) have made their ways behind the former Iron Curtain under either new or rediscovered forms during the last 30 years, alongside their pandant, the political arts.

While these artistic practices are known under a variety of names (participatory, collaborative, community-based, public art, etc., but also documentary-based, and, in the case of performative arts, theatre of the real Martin, 2013), encompassing a variety of media, focus points and aesthetics, what all of them share is an interest in (collaborative) processes instead of products, in communitarian approaches, or in the reevaluation of the artist-spectator dynamics, and the use of a large and diverse set of sociological, anthropological and/or ethnographical tools (Bishop, 2012; Magris and Picon-Vallin, 2019).

At the same time, artists working in social practice share a common believe in arts as instruments of social and political change, constantly negotiating between the aesthetical tradition and the utilitarian value of art as enabling actual social change (Hammond and Steward, 2008).

One of the countries in the region where the 'social turn' (a term coined by art historian Claire Bishop in 2006) has been the most visible, especially in performing arts, is Romania, where, for instance, the umbrella term 'documentary theatre' is used for a wide range of approaches dealing with contemporary events, local communities, ethnic groups, etc., in forms of critical approach which emphasize exclusively the connection with the real.

\footnotetext{
${ }^{1}$ Faculty of Theatre and Film, Babes-Bolyai University, cultural manager and curator for performing arts at ColectivA Association and The Paintbrush Factory Cluj-Napoca, email: miki@colectiva.ro.

2 Performing arts critic and curator, email: iuliapopovici@gmail.com.
} 
This special issue focuses on the present and recent history of socially/ politically-conscious or socially/politically-engaged arts in Romania and, largely, in the context of former European communist states in (but not exclusively) visual arts/arts in public space and performing arts (in fact, theatre), with special attention to the intersection and cross-pollination between artistic and sociological practices, from a practice-based or theoretical/analytical perspective, also tackling the terminological debate going on internationally around these forms of art (Martin, 2013).

In his article on the "Genealogy of political theatre in post-socialism. From the anti-«system» nihilism to the anti-capitalist left", theatre director David Schwartz makes a practice-based, historical approach to the vast (since very eclectic) spectrum of socially-conscious performative projects in Romania in the last thirty years. In Schwartz's analysis, the historical tradition of a left-wing, class-sensitive, engaged theatre is not as much non-existent (he identifies its traces both before and after 1945), but unknown, unacknowledged and disregarded, especially in the theoretical field and clearly in the nowadays mainstream theatre. Which means that, in the end, the emergence of a political theatre after 1990 in Romania is the result of a both personal and collective journeys involving accidental mentoring (through one theatre university professor in Bucharest) and learning from one another, international experiences and the traumatic waking up brought by the latest economic crisis. Through his direct experience as a vocal and established member of this group of political artists, Schwartz tackles the distinct voices that broke first with the "art for art's sake" mainstream tradition and the birth of the "engaged art" in the theatre, bringing alongside the practice of collective creation and the focus on representing the under-represented - the oft-quoted "giving a voice to the voiceless". In Schwartz's view - which doesn't cover the distinct formal artistic strategies involved -, the core of all these endeavours is the criticism of capitalism, from the specific perspective of the East-European periphery, and it has been exactly this critical approach that made the discussed political theatre marginal and underdiscussed, and its legitimacy, questioned (up to the point when some such political artists became recognized internationally). Even so, he identifies an important impact, which the decades-long persistence of the political theatrical discourse ended up having: the politization, at the opposite pole, of the mainstream, formerly "art for art's sake", theatre.

In a more technical - and, this time, formal - approach, largely based on the international theoretical literature about documentary-based theatre, Iulia Popovici takes in "Tortuously Turning Reality into Theatre" a particular example of practice in the theatre of the real (a concept she prefers to "documentary theatre"), that of the Moldavian artist Nicoleta Esinencu - one of the names that David Schwartz mentions in his review of the documentary landscape and the one that Schwartz states to have the most in common in term of working modes - in order to cast a new light on the ethics and aesthetics of this theatre. 
Starting from an on-purpose interview and using a kaleidoscopic system similar to Schwartz's, the article deals with the ethical and formal challenges of the central issue in the work of documentary artists - the representation of (underrepresented) realities (Stuart, 2017; Feldman, 2018). By doing so, it takes further the discussion started by Schwartz in terms of how the criticism of the current social and political systems is articulated through representations of personal, community-relevant stories not only in Romania per se but in a larger regional context. The two texts are deeply interconnected in looking at different facets of the same body of performances - the thematical one, the engagement motivations, the conventions and strategies of representation and the decision-making processes in the theatre of the real. One distinct aspect that Popovici's article covers is the professional specifics of working with documentary materials in the theatre, as compared to the use of similar materials in fields such as journalism and sociology, and the role of non-professional performers in the theatre of the real (Martin, 2006; Malzacher, 2008; Cantrell, 2013).

Marina Mironică and Miki Braniște's articles can be viewed in the mirror, both texts being informed by the authors' cultural work practice at the same time as their research interest. The starting point for Mironică's approach is the ethnographic analysis of the cultural workers active within the Paintbrush Factory contemporary art space in Cluj, a landmark for the local history of independent visual and performing arts as well as a space for cultural and civic dialogue and debate. The Paintbrush Factory was the first major project - a grassroots one - to convert a post-industrial space into a cultural space in Romania, a symbolic moment for local urban regeneration policies that connects internationally with similar movements (Zukin, 1996). Braniște, one of the founders of the Paintbrush Factory, analyzes the register of existence and development of the practices and the discourse of social art in Cluj, starting from the example of the said venue.

On her part, Mironică uses sociological theories and factual interviews to understand the phenomena the presence of the Paintbrush Factory has generated on the existence of the city, in an ethnography-framed approach, while Braniște uses auto-ethnography tools to interconnect theoretical references and interpretations of documents such as activity reports and organisational strategies. Both authors focus on the contribution of culture to the development of the city and how it is used by the city hall in order to create adherence to new urban policies, whose end result is the increasing of prices for real estate and rents and the gentrification of the outlying areas (Harvey, 2013). All this led to the loss of space including for the Paintbrush Factory in December 2019.

Mironică's initial assumption is that cultural workers, as part of a middle class, are an indispensable element of the culture-led development strategy put into motion by the local municipality since culture was reframed as a profitable resource. She is interested in how The Paintbrush Factory has evolved from an imagined community of artists to a contemporary art institution and what 
does this evolution means in the context of a peripheral city in full urban and economic growth. Her article dwells into the struggle for emancipation and social awareness that animated the activity of a relevant part of the members of the Paintbrush Factory, in order to put it in relation with the local authorities' interest for global economic competitiveness and the ensuing result of the commodification of culture.

The opening and spatial expansion of the Paintbrush Factory is connected to a particular moment in the existence of the city - the impact of the latest economic crisis on the plans for the reconversion of former industrial spaces. After the economic recovery and the implementation of new urban policies, the contraction of this artistic and community project ended up in the loss of the space. Braniște's article covers both the activity of the precursors of the Paintbrush Factory and that of its members, which produced tactics in relation to the realities of the context in which they operate, framing said activity as being of a reactive type.

Stating the need for a more stable and broader tactical framework, Braniște analyzes several moments conducive to developing a strategy: the creation of the critical mass, the possible institutionalization of the Paintbrush Factory or the insertion of a social vision on the arts in the cultural strategy of the city. By exploiting an organically developed cultural model (the Paintbrush Factory), the city of Cluj manages to create a new narrative of the city, consolidating it in the direction of the creative city. This strategy results in the intensification of gentrification (already existing for other causes) and it makes Cluj yet another city whose policies of urban regeneration fail the inhabitants and generate social inequalities (Peck, 2007).

Through both their similarities and their differences, the two texts, by Mironică and Braniște, present the image of the current Cluj, presenting the Paintbrush Factory as exemplary for the effects of particular municipal urban policies.

\section{REFERENCES}

Claire Bishop (2006). The Social Turn: Collaboration And Its Discontents. Artforum. 01.02.2006. www.artforum.com/. (Accessed on 10.12.2019).

Bishop, Claire (2012). Delegated Peformance: Outsourcing Authenticity. CUNY Academic Works. http://academicworks.cuny.edu/gc_pubs/45.

Cantrell, Tom (2013). Acting in Documentary Theatre. Basingstoke: Palgrave Macmillan.

Feldman, Benedict Alexander (2018). The Theatre of Culpability: Reading the Tricycle's Tribunal Plays through the Trial of Adolf Eichmann. Law, Culture and the Humanities, May, 2018: 1-22.

Hammond, Will, Steward Dan (Eds.), (2008). Verbatim Verbatim: Contemporary Documentary Theatre. London: Oberon. 
Harvey, David (2013). Rebel Cities. From the Right to the City to the Urban Revolution. Verso. Magris, Erica; Picon-Vallin, Béatrice (Eds.), (2019). Les Théâtres documentaires. Montpellier: Deuxième époque.

Malzacher, Florian (2008). Dramaturgies of care and insecurity: The story of Rimini Protokoll, in Dreysse, Miriam; Malzacher, Florian (Eds.). Experts of the everyday. The theatre of Rimini Protokoll. Berlin: Alexander Verlag: 14-43.

Martin, Carol (2006). Bodies of Evidence. TDR/The Drama Review. Vol. 50 (3, Fall): 8-15.

Martin, Carol (2013). Theatre of the Real. Basingstoke: Palgrave Macmillan.

Peck, Jamie (2007). The creativity fix. Eurozine. 28.06.2007. https://www.eurozine.com. (Accessed on 29.11.2019).

Young, Stuart (2017). The Ethics of the Representation of the Real People and Their Stories in Verbatim Theatre, in O'Toole, Emer; Kristić, Andrea; Pelegrí, Young Stuart. Ethical Exchanges in Translation, Adaptation and Dramaturgy. Leiden/Boston: Brill/Rodopi: 21-42.

Zukin, Sharon (1996). The cultures of cities. Wiley-Blackwell. 